receptors for this hormone in a clonal strain of rat pituitary tumour cells $\left(\mathrm{GH}_{3}\right.$ cells). These cells do not make thyrotropin (TSH) but TRH does stimulate the synthesis and release of the hormone prolactin and inhibits the formation of growth hormone by these cells. Previously it had been shown that TRH bound firmly to $\mathrm{GH}_{3}$ cells, presumably to receptors on plasma membranes of the type found in normal pituitaries (Vale et al., Endocrinology, 93, 26; 1973; Gourdji, et al., Expl Cell Res., 82, 39; 1973) and that the binding preceded the action of the hormone. According to Hinkle and Tashjian, incubation of $\mathrm{GH}_{3}$ cells for 2-3 days with TRH caused a reduction in the number of binding sites for TRH to a third of the normal level. Receptor molecules seem to be longlived and their loss itself requires active protein synthesis since cycloheximide protects the cells against receptor depletion. A consequence of such a hormone-induced loss in receptor capacity would be that it would provide a target cell with the means to regulate its sensitivity to the hormone.

Is the above example of a hormone regulating the number of its own receptor molecules a peculiarity of abnormal tumour cells or of culture conditions, or does it reflect a universal physiological homeostatic mechanism for hormones? After all, $\mathrm{GH}_{3}$ cells do not synthesise TSH whereas the action of TRH on normal pituitary cells is to control their TSH output. In another pituitary tumour cell line, $\mathrm{GH}_{1}$ cells, whose growth is influenced by thyroid hormone, Samuels and Tsai reported that tri-iodothyronine $\left(\mathrm{T}_{3}\right)$ increased the number of $\mathrm{T}_{3}$ receptors in the nucleus (Proc. natn. Acad. Sci. U.S.A., 70, 3488; 1973). But, Spindler et al. (J. biol. Chem., 250, 4113; 1975) have failed to observe a similar phenomenon for the number of $T_{3}$ receptors in normal rat liver nuclei. It may, therefore, be premature to generalise about the self-regulation of hormone receptors. Perhaps one needs to examine those systems where sensitivity of a tissue to a hormone changes very rapidly, as during ontogenesis or during certain hormone-dependent cyclical physiological situations. It may well be that the basis of the "positive feedback" phenomenon during amphibian metamorphosis may be due to marked changes in the number of $T_{3}$ receptors in the tadpole hypothalamus. Similarly, oestrogenic hormones regulating the level of their own receptors may underlie the cyclical variations in the hormonal sensitivity of the uterus during the oestrus cycle. In this context, an interesting example of induction of oestrogen receptor by oestradiol was reported by Gschwendt and Kittstein (Biochim. biophys. Acta, 361, 84;

\title{
Eruption anticipated
}

from Peter J. Smith

ON July 5-6 this year the Hawaiian shield volcano, Mauna Loa, erupted for the first time in 25 years. The renewed activity was not entirely unexpected, however, for only a few weeks before the eruption scientists at the US Geological Survey's Hawaiian Volcano Observatory had prepared a report, based on seismic and geodetic data, suggesting that Mauna Loa "may be reawakening". As it turned out, the report was overtaken in press by the event, but now that it has been published (Koyanagi et al., Geophys. Res. Lett., 2, 405; 1975) it is possible to see the evidence upon which the prediction was based.

Since Mauna Loa last erupted in 1950 , seismic activity in its vicinity has been low but not completely absent. Records covering the past 13 years show that there were several bursts of activity which reached small peaks in 1962, 1967 and 1970, each larger than the one before. But in April 1974 the frequency of small summit earthquakes increased con-

1974). These workers demonstrated that injection of oestradiol to male chicken leads to the induction of high affinity nuclear binding sites $\left(K_{\mathrm{D}}\right.$ of about $10^{-9} \mathrm{M}$ ) in the liver under conditions in which the hormone induces the synthesis of egg-yolk proteins in this tissue.

Perhaps a more common situation in which hormonal modulation of hormone receptor level may have physiological relevance is that in which one hormone controls the level of receptors for another hormone. Several complex, multi-hormone systems are known whereby one hormone conditions a tissue or a group of cells in its response to another. Two examples of such hormonal interplay are lactation, in which steroid hormones induce the mammary epithelial cells to become sensitive to the lactogenic hormone, prolactin (see Topper, Recent Prog. in Hormone Res., 26, 287; 1970) and the sensitivity of the chick oviduct to progesterone being dependent on previous stimulation by oestradiol (see O'Malley et al., Recent Progr. in Hormone Res., $25,105 ; 1969)$. It is therefore of some interest that oestrogen induces a cytoplasmic $7 \mathrm{~S}$ receptor for progesterone both in the chick oviduct (Toft and O'Malley, Endocrinology, 90, 1041; 1972) as well as in the hamster uterus (Reel and Shih, Acta Endocr., 90, 344; 1975). With interest in the above phenomena increasing rapidly, it is safe to predict that many "hormone receptorology" papers will be dealing with the regulation of hormone spicuously, reaching hundreds to thousands a day for a week in midAugust, more than a week in midDecember and for many days between February and June 1975. Throughout the whole period 1962-1975 magnitudes ranged up to 4.6 but most of the events with magnitudes greater than 3 occurred during 1974-75.

During the latter period the shocks generally became not only larger but also shallower than before. Most of the foci were at depths of less than $15 \mathrm{~km}$, although a few reached $50 \mathrm{~km}$. Moreover, there was an earthquakefree zone at depths of $15-30 \mathrm{~km}$ beneath the summit crater, believed to indicate a magma storage region. The epicentres defined a broad seismic zone around the summit where dilation was evidently also occurring. Thus geodimeter measurements showed that a $2.5 \mathrm{~km}$ line across the summit caldera expanded by $10 \mathrm{~cm}$ between August 1974 and June 1975.

Taken together, these data strongly indicated a resumption of volcanic activity, although they were far from sufficient to enable the time of any eruption to be predicted.

receptor levels. Whatever the outcome of such efforts, the important issue will still be the perennial question of how does one equate hormone binding with the site, or sites, of relevant physiological actions of a given hormone.

\section{A most Friendly meeting}

from Natalie Teich and Paul Harrison

The Friend Cell Workshop was held at Schloss Reisenburg, West Germany, on August 28-September 1.

THE workshop established the relevance of the Friend virus-Friend cell system as a model for erythropoietic differentiation, for multiple host gene control of erythroblastic disease and for studies of the relationship between cell transformation and abnormal differentiation.

The cell biology of the Friend cell system was a major topic. Friend virus (FV) infection of susceptible mice results in enhanced erythroblastosis and polycythemia or anaemia (the original virus strain of $\mathrm{Dr} C$. Friend) due to massive cell death in the early erythroblast compartment (C. Jasmin, Hôpital Paul Brosse, Villejuif). It now seems established that the target cell for $\mathrm{FV}$ is a committed erythroid stem cell (CFU-E) (P. Tambourin, Radium Institute, Paris). Axelrad's group (Uni- 